\title{
An Evaluation of DepEd-produced Grade 7 Biology Modules by Biology Experts and Science Teachers
}

\author{
Maria Lourdes G. Tan ${ }^{\mathrm{a}}$ \\ Corresponding author: Maria Lourdes G. Tan (marialourdestan71 @ gmail.com) \\ Leyte Normal University, Tacloban City, Leyte, Philippines 6500.
}

Keywords: biology experts, teachers, modules, evaluation

\begin{abstract}
Teachers play an essential role in the evaluation of learning materials. As facilitators of learning, they ensure that learning materials serve their purpose of bringing about the effective teaching-learning process. This study aimed to evaluate the Department of Education (DepEd)-produced Grade 7 Biology Modules as perceived by Biology Experts and Science Teachers in the 16 public secondary schools in the Division of Tacloban City, Leyte, Philippines. The modules are evaluated based on the seven dimensions: a) content, b) presentation and organization, c) learning activities, d) evaluation activities, e) accuracy and up-to-dateness of information, f) format and g) sufficient availability of materials. The demographic profile of 17 Biology experts showed that the majority are female, BSED graduates in Biological Sciences with a doctoral degree in Biology and 1-15 years teaching Biology subjects. Grade 7 Science teachers are mostly females who have a bachelor's degree in Biological Sciences, with master's units and 1-2 years teaching Grade 7 Science in the K to 12 Curriculum. Biology experts and science teachers assessed the five modules using descriptive survey method employing quantitative and qualitative analysis. They both evaluated the modules satisfactory in the seven dimensions. However, they pointed out suggestions for improvement of the modules.
\end{abstract}

\section{Introduction}

Science education is greatly affected by globalization which poses challenges on its alignment with the current perspective on global competencies. In the Philippines, the $\mathrm{K}$ to $12 \mathrm{Basic}$ Education Curriculum was implemented to keep abreast with global trends. It was also challenged to improve the low scores of Filipino students in the 2003 Trends in International Mathematics and Science Studies (TIMMS), where the Philippines ranked 43rd among 46 countries regarding science studies (TIMMS, 2013). The low International Science achievement results were also felt in the 2012 National Achievement Test (NAT) in which among the five core subjects, science got the lowest mean percentile score (MPS) (Naval, 2014). The weak results were confirmed in the report of Education Secretary Armin Luistro on March 28, 2012, on the 2011 NAT result, which stated that primary students had a failing national average of $68 \%$, while secondary students had a failing national average of $47 \%$ (Ronda, 2012). To solve the challenges of science education in the Philippines and carry out the effective implementation of the K to 12 Curriculum, the Department of Education (DepEd) mandated the allocation, delivery, and distribution of modules used by teachers and learners (DepEd Order No. 31, s. 2012). However, the learning modules used at the start of the K to 12 Program implementation have received much feedback, both positive and negative. As background, there is a report of the results of some local studies like that of Sañosa (2013) which disclosed that despite the training conducted by DepEd on the K to 12 Curriculum, some teachers commented that the Grade 7 Biology Modules were complicated regarding required teaching competencies. Another finding was revealed by Gutierrez (2014) in which students 
experienced difficulty in understanding biological concepts in the Grade 8 Biology Module. Furthermore, students became discouraged with the subject because of complex vocabulary that needs to be memorized to understand the topic. On the other hand, even after the implementation of the $\mathrm{K}$ to 12 Curriculum and the use of the learning modules, the National Achievement Test (NAT) results, particularly in the Division of Tacloban City still showed a low mean percentage score (MPS) in Science and Mathematics. This result motivated the researcher to use the Division of Tacloban City as the locale of her study.

Given the feedback above, the researcher saw the need to evaluate the DepEd-produced Grade 7 Biology Modules utilised by teachers as learning materials. It was the ultimate goal of this study to evaluate and enhance the five Grade 7 Science - Living things and their Environment - Modules. Specifically, the study conducted sought to answer the following questions:

1. What is the profile of the biology experts and Grade 7 Science teachers in terms of the following?
a) sex and age
b) educational qualification
c) length of service in teaching Grade 7 Science of $\mathrm{K}$ to 12 Curriculum

2. What is the level of perception of biology experts and Grade 7 Science teachers of K to 12 Curriculum on the Living Things and their Environment Modules in the following dimensions?
a) content
b) presentation and organization
c) learning activities
d) evaluation activities
e) accuracy and up-to-dateness of the information
f) format
g) sufficiency on availability of modules

3. What are the suggestions of the biology experts and Grade 7 science teachers for improving the Grade 7 Science Living Things and their Environment Modules in the following dimensions?
a) content
b) presentation and organization
c) learning activities
d) evaluation activities
e) accuracy and up-to-dateness of the information
f) format
g) sufficiency on availability of modules

The researcher recognized that said modules were the product of the collaborative efforts of experts in the field of science from the National Institute of Science and Mathematics Education (NISMED). But, knowing that those were the first outputs for the first year of implementation of the $\mathrm{K}$ to 12 Curriculum in 2012, it is then necessary to assess the Grade 7 Biology Modules from Biology experts and teachers. As explained by Bago (2001) the implementation of the program without assessment is much like a dying patient who goes to a doctor to get medicine for a fatal illness but never returns to the medical office to see if the medicine has the needed effect.

One important question to ask is: Why is there a need to evaluate the modules? Pawson (2013) explained that evaluation is conducted to inform the improvement of policy and practice. He added that science could only grow if it learns lessons from investigation to investigation rather 
than each inquiry emerging freshly out of the egg. Newby, Stepich, Lehman and Russell, (2006) mentioned three criteria in evaluating instructional materials, namely: 1) usefulness related to pedagogical effectiveness, 2) usability related to perceptual and technological efficiency, and 3) appeal. Furthermore, Newby identified five goals in evaluating instructional materials as follows: 1) to help assess the effectiveness of the instructional material; 2) to improve one's skills in instructional material development; 3) to determine whether the instructional materials comply with specified standards; 4) to contribute to the knowledge of evaluation theories, and 5) to improve the instructional materials (IMs). Hamona (2002) also cited criteria for evaluation of instructional materials developed by the UNICEF Curriculum Development Project as follows: a) material should cover the required learning competencies, b) provision for appropriate evaluation activities with indicators for the degree of attaining the learning competencies, and c) time allotment to cover the lesson or unit.

Two evaluation theories guided this investigation: Formative Evaluation and Developmental Evaluation Theory. Scriven (1967) coined the first theory, which includes the following steps: 1) improving, 2) enhancing, and 3) standardizing. Flagg (1990) introduced four phases of formative evaluation as follows: Phase 1-Planning, Phase 2-Design, Phase 3-Production, and Phase 4-Implementation. In Planning, needs assessment is conducted to include perceptions, habits, knowledge, skills, and expectation. In Design, it contains decisions regarding specific content, objectives, and instructional strategies. The production consists of decisions on issues that affect concerns on appeal, comprehensibility, user-friendliness, pacing, and icons. Finally, the Implementation phase is done to help in the enhancement of support materials like print materials or to inform designers of the need for some changes.

Evaluating to make improvements is known as formative evaluation, which examines the content, input, and process of the curriculum, and its learning materials (Phillips, 2013). It also allows the evaluator to evaluate the instruments to be used. If any section of it does not yield data useful for instruction, then it should be revised or eliminated (Dick, Carey, \& Carey, 2001). The Developmental evaluation theory of Patton (2011), on the other hand, emphasized that one of the strategies to measure the effect of a program is to generate feedback and learning. Hattie and Timperly (2007) stressed that feedback, as a form of assessment, is one of the most effective influences on learning and achievement. But the impact can either be positive or negative. Feedback from teachers or experts in the field is often used to make improvements to the learning materials. Race (2000) stated that feedback is one of the most important considerations when assessing instructional materials. Thus in this study, input from Biology experts and Grade 7 science teachers about the quality of the biology modules as used by them during instruction is very vital information in evaluating the materials by actual use in the classroom.

Within the context of the theories outlined above, the researcher developed a conceptual paradigm illustrated in Figure 1 which helps visualise the entire study. 


\section{Conceptual framework}

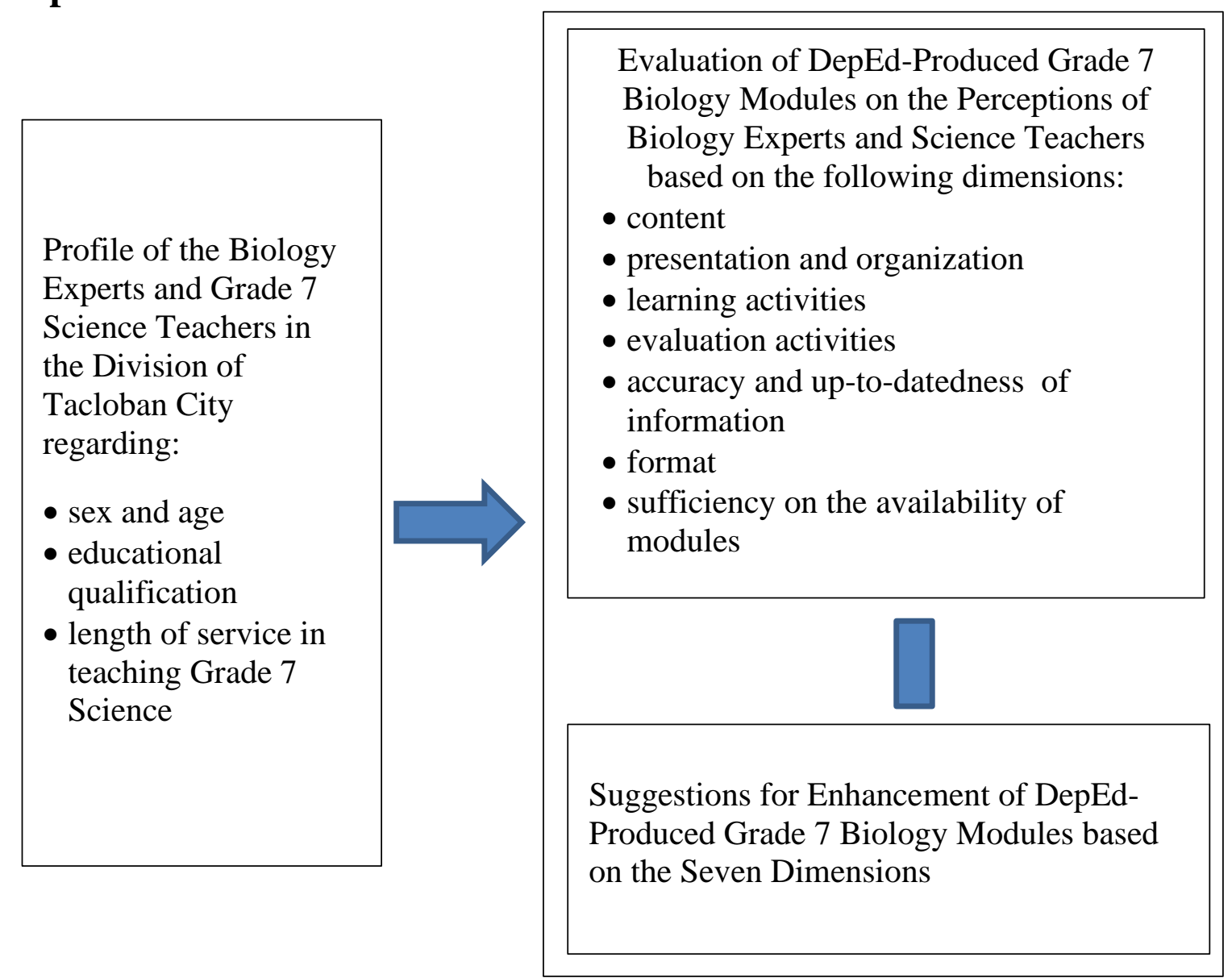

\section{Figure 1. The Conceptual Framework of the Study}

\section{Methodology}

\section{Research design}

The study utilised a descriptive survey method using a survey questionnaire to collect quantitative and qualitative data. It was concerned with the evaluation and suggestions for the improvement of the module. This study was conducted in the Division of Tacloban City, Leyte, Philippines.

\section{The respondents}

The 17 Biology experts and 35 Grade 7 science teachers of 16 public secondary schools comprising the entire Division of Tacloban City were requested to serve as respondents with the approval beforehand from the school's division superintendent and principals.

\section{Sampling}

In choosing the respondents, no sampling was done since all the teachers teaching Grade 7 Science were respondents of the study. The teacher respondents were public secondary school teachers of the Division of Tacloban City, Leyte, Philippines. Both Biology experts and Grade 7 Science teachers were identified regarding their demographic profile characteristics as sex and age, educational qualification, and length of service in teaching Grade 7 Science in the K to 12 Curriculum. However, Biology experts were chosen regarding their length of service in teaching Biology. 


\section{Materials}

\section{Grade 7 Biology Modules}

These refer to science learning modules used in teaching Grade 7 Biology. The Department of Education provided the said material under the K to 12 Basic Education Curriculum, which has undergone series of validation and pilot testing by the Department of Education before its implementation (K to 12 Science Curriculum Guide, December 2013). Specifically, the Grade 7 Biology Modules referred to in this study is usually recited during the Second Quarter between August, September, and October.

Curriculum content standards reflected in the Curriculum Guide (2013) of the Grade 7 Biology Modules include: parts and functions of compound microscope; different levels of biological organization as to: cells, tissues, organs, organ system, and organisms; how organs work together in plants and animals; organisms and structures other than plants and animals; process of reproduction, both sexual and asexual; and, the interaction of these organisms with nonliving things in the ecosystem.

\section{Assessment of Grade 7 Biology Modules}

The ADDIE Model (Analyze, Design, Develop, Implement, and Evaluate) by Watson, Murin, Vashaw, Gemin, and Rapp in Tampa, 2013 was the basis in the primary procedure of the study. The analysis phase involves the gathering of information about the modules based on the seven (7) dimensions from the Grade 7 Science teachers who assessed the modules. The design included areas to be evaluated, as well as the instrument and procedure to gather the data. Development of this study made use of the perceptions and suggestions of Biology experts and teacher-respondents in enhancing the Grade 7 Biology Modules. Implementation reflected the incorporation of Biology experts' and teachers' feedback to improve the modules.

\section{Dimensions in evaluating the Grade 7 Biology Modules}

The content of learning materials: The content of materials refers to the lessons and learning competencies and skills needed to be acquired by the learner in the subject (Macarandang, 2009). Teachers should take note that in selecting a material for instruction, one must be guided by the following questions: (1) Is this material usable to the teaching curricular unit, specific learning experience or problem-solving activity?, (2) Do the learning instructional materials (IMs) contribute meaningful content and learning experience?, (3) What is the degree of relationship between curricular content of the learning material and subject matter to be learned?, and (4) Is the content of the material sufficiently rich with number of examples to warrant sound conclusion? (Abolade, 2013).

Presentation and organisation: This implies that the sequence of topics in the curriculum guide is consistent with the topics in the module. Salandanan (2011) defined presentation and organisation as the logical and smooth flow of ideas, in which it followed pattern of experiences to provide the learner with accumulative understanding and skills.

Learning activities: This refers to the activities in the module that provide opportunities and experiences for students to develop integrated science process skills or higher-order thinking skills.

Evaluation activities: The Grade 7 Biology Modules include assessment of activities and concepts in the form of a pretest and posttest following principles of test construction congruent to learning competencies and specific objectives (Macarandang, 2009). 
Accuracy and up-to-dateness of information: This refers to all errors in the modules such as conceptual, grammatical, factual, computational, typographical and other minor errors (for example: inappropriate or unclear illustrations, missing labels, wrong captions, and other) and obsolete information (DepEd Regional HandBook in the Context Evaluation of Supplementary Materials, IMCS, 2008).

Format: DepEd Regional HandBook (2008) identified the following criteria to evaluate the format of the learning material which include/s: a) prints in term of size of letters and space between letter and words, b) illustrations, c) designs and layout, d) paper and binding, and e) size and weight of module.

Sufficiency on availability of modules: This refers to the manner of establishing the number of copies of the said materials vis-à-vis the number of students who are using the materials and the teachers involved in Grade 7 Science instruction.

\section{Instrument}

The research instrument, which is the researcher-made questionnaire consists of two parts:

Part 1 - Expert and Teacher Respondent Profile. This refers to the background information of Biology experts and Grade 7 science teachers regarding sex and age, educational qualification, and length of service in teaching Grade 7 Science in the K to 12 Curriculum.

Part 2 - Experts' and Teacher's Perceptions of Grade 7 Biology Modules. It dealt with determining the Biology experts' and teacher's perceptions of the Grade 7 Biology Modules regarding content, presentation, and organization learning activities, evaluation activities, accuracy, and up-to-dateness of information, format, and sufficiency on the availability of modules.

The five significant topics evaluated in this part of the questionnaire are as follows:

a) Module 1 - From Cell to Organism;

b) Module 2 - Plant and Animal Cells;

c) Module 3 - Living Things Other than Plants and Animals;

d) Module 4 - Reproduction: The Continuity of Life; and,

e) Module 5 - Interactions. Each component or aspect of the five modules has 5-14 conditions describing the characteristics of the existing module.

The said instrument was validated by 17 Biology experts and was pilot tested to 20 Grade 7 science teachers who were not respondents of the study. They were teachers who taught Grade 7 Science before, but not at present. In determining the reliability of the survey questionnaire for experts and teachers, the researcher made use of Cronbach Alpha Reliability Coefficient as the statistical tool. From the results, it can be gleaned that there were very high results in all of the areas considered for assessment. The overall result of 0.95 was interpreted as Very High Reliability. This means that the instrument has achieved consistency of responses from the respondents across all conditions given for each category of assessment, and as such, its reliability is established. From the results of the validation and reliability tests of the survey questionnaire, it was determined that the instrument was ready to use for the actual respondents. 
Table 1: Cronbach Alpha Reliability Coefficient of the Experts and Teachers' Survey Questionnaire

\begin{tabular}{|l|l|l|}
\hline Areas/Dimensions & Reliability & Description \\
\hline Content & 0.97 & VH \\
\hline Presentation and Organization & 0.98 & VH \\
\hline Learning Activities & 0.95 & VH \\
\hline Evaluation Activities & 0.99 & VH \\
\hline Accuracy and Up-to-dateness of Information & 0.95 & VH \\
\hline Format & 0.91 & H \\
\hline Sufficiency on Availability of Materials & 0.93 & H \\
\hline Overall & $\mathbf{0 . 9 5}$ & VH \\
\hline
\end{tabular}

Legend:

$\begin{array}{lll}0.95-0.99 & \text { (VH) } & \text { Very High Reliability } \\ 0.90-0.94 & \text { (H) } & \text { High Reliability } \\ 0.80-0.89 & \text { (FH) } & \text { Fairly High Reliability } \\ 0.70-0.79 & \text { (RL) } & \text { Rather Low Reliability } \\ \text { Below 0.70 } & \text { (L) } & \text { Low Reliability }\end{array}$

The assessment on the DepEd-produced Grade 7 Biology Modules as perceived by the Biology experts and teacher-respondents manifested their ratings of each statement using a scale of 41, where 4 is equivalent in Very Satisfactory (VS), 3 as Satisfactory (S), 2 as Poor (P), and 1 as Not Satisfactory (NS). It also includes the suggestions of the evaluator on the enhancement of the module. It uses the range of value adapted from Rodriguez (2015). The qualitative remark is adapted from DepEd Regional Handbook in the Content Evaluation of Supplementary Materials, IMCS (2008).

\begin{tabular}{|cl|}
\hline Scale & \multicolumn{1}{c|}{ Description } \\
$3.51-4.00$ & Very Satisfactory (VS) \\
$2.51-3.50$ & Satisfactory (S) \\
$1.51-2.50$ & Poor (P) \\
$1.00-1.50$ & Not Satisfactory (NS) \\
\hline
\end{tabular}

Figure 1: Method of Scoring

Source: DepEd Regional Handbook in the Content Evaluation of Supplementary Materials, IMCS (2008)

Frequency counts were used to analyse the demographic profile of the Biology experts and Grade 7 Science teacher-respondents. The options that obtained the highest frequency were treated as the dominant characteristics of the respondents. Results of the interpretation served as the derived profile of the Biology Experts and Grade 7 Science Teachers. The weighted mean was employed in determining the quality of Grade 7 Biology Modules as perceived by Science teachers and Biology experts in the seven dimensions of evaluating the instructional material. Weighted mean per dimension was computed by adding the total rating and divide it to the total number of teacher respondents. Overall weighted mean was computed by adding the total mean per dimension and divide it to the seven dimensions. Same process was done in getting the weighted mean of biology experts. Ratings were tabulated and interpreted through the use of computer assisted statistical tools. Specifically the weighted mean for each dimension with corresponding qualitative description and the overall mean were used in determining the results of the evaluation of modules. The item which had the highest mean 
score was the considered as the dimension that best described how the respondents perceived the Grade 7 Science module.

\section{Results}

Majority of the experts are female, they were master's degree holders in Biology $(9,53 \%)$, with doctoral units in Biology $(3,58 \%)$, or with doctoral degrees in Biology (5, 29\%). Age is cluster between $31-40$ years old $(7,41 \%), 51-75$ years old $(6,35 \%)$, $41-50$ years old $(3,18 \%)$, and 23 30 years old $(1,6 \%)$. Most of them or $8,47 \%$ have taught for $1-15$ years; $6,35 \% ; 16-25$ years, $2,12 \%, 26-35$ years and 1,6\% 36-45 years respectively.

The Grade 7 Science teachers in Tacloban City Division were dominated by females $(26 ; 74 \%)$ and with a less number of males $(9 ; 26 \%)$. The age of the teacher's cluster between 23-40 years old $(25,71 \%)$ followed by age range $41-45(7,20 \%)$, and last 51-60 (3, 9\%). Regarding educational attainment, the majority of the teacher respondents' have completed the undergraduate course BSED $(29 ; 83 \%)$, and the others have non-education degrees $(6 ; 17 \%)$. The BSED graduates are Biological Sciences majors (16; 46\%), General Science $(5 ; 14 \%)$, Natural Science (4; 11\%), Physical Sciences (3; 9\%), and Chemistry (1;3\%). Non-education graduates are those who are graduates in other fields such as BS Nursing (1) and BS Biology (5). Out of the six non-education graduate respondents, four have 18 education units, and two are Teacher Certificate Program (TCP), graduates. Out of the 35 teacher respondents, 9 or $26 \%$ have a lower educational qualification (e.g., BSED/BS with education units); with master's units $(14,40 \%)$; with a master's degree $(11,31 \%)$; and 1 or $3 \%$ with a doctor's degree. In terms of years in teaching Grade 7 Science under the K to 12 Curriculum, majority of the teachers, or 11 or $31 \%$ have taught for only one year; 10 or $29 \%$ have taught for two years; four or $11 \%$ for three years; two or $6 \%$ have taught for four years; and eight or $23 \%$ have taught for five years, while most experts 8 or $47 \%$ have taught biology for 15 years.

\section{Biology experts' quantitative evaluation}

The DepEd produced Grade 7 Biology Modules got satisfactory quality in all the seven dimensions from Biology experts with an overall weighted mean of 3.47. Evaluation was based on the seven aspects of evaluating instructional materials according to the major area of concern that needs utmost attention and action: 1) sufficiency on availability of materials, 2) presentation and organization, 3) format, 4) content, 5) learning activities, 6) evaluation activities, and 7) accuracy and up-to-dateness of information.

\section{Grade 7 science teachers' quantitative evaluation}

The Grade 7 Science Teachers also evaluated the module satisfactory in all seven dimensions. However, they differ in the major area of concern as follows: 1) sufficiency on availability of materials, 2) content, 3) presentation and organization, 4) learning activities, 5) evaluation activities, 6) format and 7) accuracy and up-to-dateness of the information.

\section{Consolidated description of biology expert and Grade 7 science teachers' quantitative evaluation.}

Content: Certain conditions in these aspects were not fully met like the provision of sufficient discussion of concepts and glossary of terms.

Presentation and organization: The sequence of topics in the curriculum guide is not consistent with the series of issues in the learner's material and teacher's guide. De la Cruz 
(2015) pointed out that instructional materials need to have relevance for the objective of the lesson. Ali (2010) agreed that the stated objectives of the module lead to instructional quality.

Learning activities: The teacher respondents stated that the learning material presents more activities than discussion, particularly for basic science process skills. Biology Modules lack the integrated science process skills which allow students to learn what it means to do science by applying experimental skills, solving problems, and developing thinking skills. They are frustrated since most of them cannot perform the activities due to lack of learning materials (printed textbooks), science apparatus, and specimens. Macarandang (2009) explained that enrichment activities enhance student's learning of the concepts.

Evaluation of activities: Students can download from the DepEd website the assessment of the lesson. It needs immediate action to ensure that teachers are evaluating the actual learning of students.

Accuracy and up-to-dateness of information: There is a need to correct some conceptual, grammatical, and typographical errors in the module. Chinwendu (2014) explained that lexicosyntactic errors contained in the teaching materials if not fixed would make students merely the conveyor belt of errors contained in the teaching materials.

Format: Regarding format, the clarity, illustrations, pictures, and appropriateness of colors still need enhancement. As explained by Olurinola (2015), colors have a positive effect on the attention-retention rate of students inside the classroom.

Sufficiency on the availability of modules: It needs utmost attention and action. Results were validated by the researcher herself when she conducted her pre-survey which revealed that most or $38 \%$ of the 16 schools included in the study have one book is to two to five students ratio of Learner's Materials; 69\% have no Teacher's Guide; and 75\% have no laboratory equipment/materials, especially the microscope since typhoon 'Haiyan' destroyed it. According to Oakes and Saunders (2002) textbooks and learning materials are the primary tools for learning. It promotes efficiency in the teaching-learning process. De la Cruz (2015) pointed out that the inability for students to use books for reading negates the objective of teaching and make the teaching-learning process unproductive. 
Table 2: Summary Evaluation of DepEd-Produced Grade 7 Biology Modules based on the Biology Experts' and Teacher-Respondents' Perception

\begin{tabular}{lllllll}
\hline \multirow{2}{*}{ INDICATORS } & \multicolumn{2}{c}{$\begin{array}{l}\text { Teachers' } \\
\text { Perception }\end{array}$} & $\begin{array}{l}\text { Biology } \\
\text { Experts' } \\
\text { Perception }\end{array}$ & \multicolumn{2}{c}{$\begin{array}{l}\text { Combined } \\
\text { Perception }\end{array}$} \\
\cline { 2 - 7 } & Mean & Desc & Mean & Desc & Mean & Desc \\
\hline 1. Content & 2.98 & $\mathrm{~S}$ & 3.45 & $\mathrm{~S}$ & 3.22 & $\mathrm{~S}$ \\
2. Presentation and Organization & 2.98 & $\mathrm{~S}$ & 3.41 & $\mathrm{~S}$ & 3.20 & $\mathrm{~S}$ \\
3. Learning Activities & 3.03 & $\mathrm{~S}$ & 3.48 & $\mathrm{~S}$ & 3.26 & $\mathrm{~S}$ \\
4. Evaluation Activities & 3.06 & $\mathrm{~S}$ & 3.52 & $\mathrm{VS}$ & 3.29 & $\mathrm{~S}$ \\
5. Accuracy and Up-to-datedness of & 3.31 & $\mathrm{~S}$ & 3.67 & $\mathrm{VS}$ & 3.49 & $\mathrm{~S}$ \\
$\quad$ Information & 3.09 & $\mathrm{~S}$ & 3.44 & $\mathrm{~S}$ & 3.27 & $\mathrm{~S}$ \\
6. Format & 2.62 & $\mathrm{~S}$ & 3.29 & $\mathrm{~S}$ & 2.96 & $\mathrm{~S}$ \\
7. Sufficiency on Availability of & 3.01 & $\mathrm{~S}$ & 3.47 & $\mathrm{~S}$ & 3.24 & $\mathrm{~S}$ \\
$\quad$ Materials & & & & & & \\
$\quad$ OVERALL WEIGHTED MEAN & & & & & & \\
\hline
\end{tabular}

Legend: 3.51-4.00 (VS) Very Satisfactory, 2.51-3.50 (S) Satisfactory, 1.51-2.50 (P) Poor, 1.00-1.50 (NS) Not Satisfactory

Biology Experts' and Grade 7 Science Teachers' Consolidated Qualitative Suggestion on the Enhancement of the Modules

Regarding content, they suggested that there should be comprehensive discussion before and after each module, with glossary of terms, and summary. In the area of presentation and organization, there is a need for alignment of topics to be consistent in the Curriculum Guide (CG) with the Teacher's Guide (TG) and Learner's Material (LM). Further, regarding learning activities, students need exposure to science inquiry activities with more emphasis on the acquisition of integrated science process skills for them to develop their higher thinking skills and become independent learners. In the area of evaluation activities, there is a need to have varied objective types of pre- and post-assessment items after each module. Minor typographical errors must be looked and corrected.

Regarding format, pictures, illustrations, and diagram must be clear and colored. Similarly, the actual color of specimens should be used to avoid misconception on the part of the students. Font style and size should have distinction for emphasis on essential concepts. The respondents emphasized the need for sufficiency of resources and laboratory materials.

\section{Discussion}

Generally, the study looked into the strengths, weaknesses, gaps and limitations, as well as the worth and merit of the learning materials which served as bases in the advancement of some initiatives or measures for improvement. Rossi, Lipsey and Freeman (2004) emphasised that evaluation is a systematic determination of a subject's merit, worth and significance using criteria geared towards an attempt to analyze what is ideal against what is really happening in the actual classroom scenario. Clark (2010) explained that evaluation of materials like formative evaluation does not only help improve the learning materials but also forms the basis on which proper learning intervention can be given in order to help the learners master the required skills and knowledge. 
In the profile of Grade 7 science teachers, results were shown in terms of sex and age, educational qualification and length of service in teaching Grade 7 Science of $\mathrm{K}$ to 12 Curriculum. The data indicate that there exists a slow upgrading of educational attainment among teachers. This has implication on teacher's competence in evaluating the learning materials. As Rouse (2005) suggested, in evaluating materials for instruction, competence is one of the guiding principles for quality evaluators. However, in terms of educational qualification of Biology experts, majority are BSED graduate major in Biological Sciences. Most of them have master's degrees or Doctoral degree in Biology which indicates their competence in evaluating the Biology content of the modules.

Moreover, in terms of length of service in teaching Grade 7 Science of the $\mathrm{K}$ to 12 Curriculum, among 35 teacher respondents, majority have taught Science since the start of the K to 12 Curriculum for at least one year but had no chance to refine their teaching of the Grade 7 Science - Living Things and their Environment Modules in the succeeding years. Problems arise when teachers cannot use the learning material appropriately since they lack mastery of the subject matter. These findings could give insights to school heads in terms of loading of subjects to teachers. Considering that there are few teachers, team teaching could not be realiszed in all schools. As suggested by one of the Biology experts: "a possible solution could be assigning a certain teacher to teach the subject for five years straight in order to gain mastery of content". However, on the part of the experts, most of them have been teaching Biology from 15 to 25 years, which presumes their mastery of the content.

\section{Level of perception and suggestions of teachers}

The teachers' overall perceptions of Grade 7 Science - Living Things and their Environment Modules, came up with an overall rating of "satisfactory". Satisfactory means errors are present but very minor and must be fixed. Sufficiency and availability of modules as the major area of concern is the weakest of all dimensions and needs utmost attention and action. According to Oakes and Saunders (2002), "Textbooks and instructional materials are the primary tools the teachers use to organize their lessons and make content knowledge and skills available to students". Therefore, sufficiency of textbooks and learner's materials promote efficiency in the teaching-learning process. Sarem, Hamidi \& Mahmoudie (2013) shared the same perception when they stated that learning materials in the form of textbooks are the heart of education due to the fact that both teachers and students are, to a large extent, dependent on books.

While it is true that competence of teachers may reinforce learning amidst scarcity of learning materials, still it cannot be denied that insufficiency and poor quality of learning materials still greatly affect learning. In the study of de la Cruz (2015) the idea was conveyed that everything relay a message. Schools that don't have enough learning materials for the students, translate into an inability for students to take home books for reading and doing homework. It negates the objective of teaching, which means that the teaching-learning process will not become productive and conducive. These problems were also expressed in some studies particularly in the findings of Ranjit (2014) who stressed the insufficiency of learning materials and the need to enhance and produce more alternative activities. The study of Koul, Fraser \& Nastiti (2018) stressed that lack of learning resources affect the quality of teaching. Teachers rely heavily on resources provided as it give them confidence in engaging with their students.

The second area of concern is content. The results of this study reveal that the materials are generally viewed by the respondents as acceptable in terms of objectives, giving the students a good understanding of the biological concepts and suitability of content to the year level of 
students. But, it must be noted that the entire conditions set for content was only rated as satisfactory and it is low in terms of its adequacy in the presentation and discussion of the content. The related studies of Mercado (2007) and Garcia (2001) revealed that when objectives in the module are made clear, specified with time allotment, it possesses a favorable degree of instructional quality. The results also confirmed the statement of Ali (2010) that clearly stated objectives have an integral role in the instructional quality of the module. Moreover, the module needs to motivate and stimulate students' interest to study Biology. This finding is similar to the conclusion of Jamwal (2012) that motivation plays an important role in learning content using modules. As what was done in the study of Sari, Hassan, Güven, \& Sen (2017), in order to convert the plan of study into action and motivate the students, materials were developed to enhance interactively students' understanding of light concepts. Salandanan (2011) further explained that module to be interesting should have contents which are relevant to the lesson and self-pacing to allow every learner to progress at his own rate. As what de la Cruz (2015) explained, the relevance of instructional materials to the objective of the lesson is an important aspect of the lesson, and an important consideration in instructional materials utilization.

The third area of concern in the assessment of the learning materials is in terms of presentation and organization wherein ratings were all satisfactory. This imply that the materials still need improvement and enhancement most particularly in terms of students' level of understanding of the new vocabulary words. Salandanan (2011) stated that modules should be written in clear and correct language suitable to the level of the target learners so as to achieve efficient communication between the learner and the module.

The learning activity aspect of the module was the fourth area of concern. One significant factor that may have contributed to the satisfactory rating was the claim by both teacher respondents and Biology experts that ninety-five percent (95\%) of the learning material are all activities for experiments. Such finding supports the lowest weighted mean which for the criterion, "the number of activities in the module is just enough for the given time allotment". However, although not the main concern, this gives insight on one of the domains of the Science Curriculum which is the acquisition of integrated science process skills through laboratory activities in the module. Villarino (2019) pointed out that, laboratory experiences likely help to achieve the conceptual understanding of the students. As revealed also by de la Cruz (2015) in Jakarta, the use of experimental science modules emphasizing integrated science process skills activities significantly improved the scores of Grade 7 and Grade 8 students on the integrated science process skills test. He added that students exposed in the experimental science module were able to identify variables, state hypotheses, define variables operationally, graph and interpret data, and design experiments, thus, developing their thinking skills to become independent learners. Therefore, module should include integrated science process skills if we want to develop or level-up the thinking process skills of students.

The fifth area of concern is in terms of evaluation activities. The material was rated satisfactory in all conditions, which signifies the usability of the items in the evaluation exercises as assessment of content learned. In assessing the materials in terms of evaluation activities, the pre-assessment and post-assessment part of the module were really utilized by most teachers as their reference for formative and summative assessment. However, an important finding came out during the interviews and focus group discussion that the Teacher's Guide can be downloaded by students so the reliability of pre- and post-assessments is weakened. This alarming observation needs immediate action to ensure that teachers are evaluating the actual learning or knowledge of students. As explained by Reardon, Scott and Verre (1994), results 
of evaluation of learning materials play a pivotal role in deciding what the students learned, what instructors teach in schools, and what teachers do as facilitators of learning.

The sixth area of concern is format. Results showed that quality of the said materials was observed to have not met the standards in terms of clarity of illustrations, attractiveness, and appropriateness of colors. In a related study conducted by Olurinola (2015) colors have positive effect on the attention-retention rate of students inside the classroom. He added that students exposed to congruent colors have better performance than those groups who are not exposed to colored teaching materials. Peacock (2007) stressed that quality of materials is important if they are to achieve the learning objectives.

The last area of concern is accuracy and up-to-dateness of information. It got the highest weighted mean among all the dimensions in the evaluation of the modules, which indicates it as the strongest among the seven dimensions. Still, the ratings provided great help in improving the learning material in this aspect. Although the result signifies that teacher respondents did not really consider it a priority to improve the module in this aspect, it is still a must to correct typographical errors and scientific concepts and information, since the material serves as the bible of the daily classroom quest for knowledge. Teachers found out some conceptual, grammatical, and typographical errors in the module. Chinwendu (2014) has stated lexicosyntactic errors contained in the teaching materials if not corrected will make students the conveyor belt of the errors contained in the teaching material. This means errors in the teaching material should be corrected so as not to multiply the commission of mistakes since most teachers and students are dependent on these materials for teaching and learning.

Along this line of thought, majority of the respondents were very optimistic and enthusiastic in their desire for the improvement of the learning material, which is the main tool for instruction. Similarly, various researches have already been conducted like that of Tomlinson (2011), Gravoso (2005) and Sitragool (2003) which attempted to develop learning materials. What makes the present study distinct from previous researches is the fact that the improvement and enhancement of the learning material is based on the suggestions of both biology experts and teacher respondents who were the users of the material and has direct contact with students. With the fifth year implementation of the $\mathrm{K}$ to 12 Curriculum, there is a need for re-evaluation of the learning materials and check if they are updated, relevant and still suited to the needs of students. On the other hand, to determine also if the material is aligned with the international standards of science education. Proper evaluation of learning materials will lead to quality learning. Without sufficient and quality learning materials, there is always the danger that learners do not acquire the necessary knowledge, skills, and attitude appropriate for them to be ready and confident in all the rudiments of learning and are equally competitive with learners in other parts of the world.

\section{Conclusions}

Biology Experts' and Grade 7 Science Teachers rated the five Grade 7 Biology modules as satisfactory along with the seven dimensions which signify the need for enhancement. The majority of teacher respondents have low levels of education, mostly, the undergraduate or bachelor's degree. A poor academic qualification may affect competence and skills for teaching science in the $\mathrm{K}$ to 12 Curriculum. Teacher respondents have limited number of years of teaching Grade 7 Science in the K to 12 Curriculum, which means they have less mastery of the content and skills, which could affect the quality of learning of the students. Based on the findings and conclusions derived from the study, there is a need to encourage more male senior 
high school graduates to take education courses in college major in Science. Retooling and training of teachers on the appropriate use and implementation of the learning modules. School administrators need also to encourage teachers to upgrade their educational qualification and give the same load to teachers for a maximum of five years for them to gain mastery of the subject taught, thus, improving their competence and skills to teach science in the $\mathrm{K}$ to 12 Curriculum.

A similar evaluation study may be undertaken to other disciplines under the $\mathrm{K}$ to 12 Curriculum most especially in science subjects using the researcher-made questionnaire. It means that findings of the study may be used to revise the existing learning materials in other areas of Grade 7 Science such as Earth Science, Chemistry, and Physics, so the enhancement of the Grade 7 modules will be complete and comprehensive. Another investigation study may be conducted using the students (in other words, the end users) as respondents of the research undertaking to have triangulation of data. As explained by Koul, Fraser and Nastiti (2018), assessing students' actual perception serve as guide in reducing learning gaps. Thus, aside from DepEd module, teachers and experts could make instructional materials (IMs) at lesser cost following the $\mathrm{K}$ to 12 competences. The said instructional materials should be responsive to the current needs of the students' by not limiting to the minimum skills but should maximize their full scientific potentials to be globally competitive. This evaluation study and its survey tool hopes to contribute data and information significant for the enhancement of the learning materials. Enhanced Grade 7 Biology Modules and their use would redound to better and improved performance of Grade 7 students in Science, specifically in Biology.

\section{Acknowledgements}

The researcher would like to extend her gratitude to Dr. Rosalina Hidalgo Coral, the administration of Leyte Normal University, Department of Education (DepEd), Tacloban City Division both in Tacloban City, Leyte, Philippines, and Commission on Higher Education (CHED) Region VIII and Central Office, Quezon City, Philippines for the help given in the completion of this study.

\section{References}

Abolade, A. O. (2013). General techniques for evaluation of learning and Instructional materials, Department of Curriculum \& Educational Technology, university of Dorin, Nigeria

Ali, R. (2010). Development and effectiveness of modular teaching in Biology at secondary level. Retrieved from http://eprints.hec.gov.

Bago, A.L. (2001). Curriculum development: The Philippine experience. De La Salle University Press, Inc. Manila, Philippines, pp.9, 175, 187

Clark, D. (2010). Types of evaluations in instructional design. Big dog and little dog's performance juxtaposition. Retrieved from http://www.nwlink.com/donclark/hrd/isd/types_of_evaluation.html

Chinwendu, P. (2014). Effects of lexico-syntactic errors on teaching materials: A study of textbooks written by Nigerians. Retrieved from http://www.journals.aiac.org.au/index.php/IJELS/article/view/235

De la Cruz, J. P. (2015). Development of an experimental science module to improve middle schools students' integrated science process skills. Retrieved from www.dlsu.edu.ph/conferences/dlsu_research_congress/2015/proceedings/LLI/018LLI_DelaCruz_JP.pdf

Department of Education Order No. (D.O.) 31, s. 2012. (2012, April 17). Policy

Guidelines on the Implementation of Grades 1 to 10 of the K to 12 Basic Education Curriculum (BEC) Effective School Year 2012-2013. Pasig City: Philippine Department of Education.

Department of Education Regional Handbook in the Content Evaluation of Supplementary Materials. IMCS., 2008.

Department of Education (2013). K to 12 science curriculum guide. Retrieved from http://depedligaocity.net/ScienceCG3-10.pdf

DepEd Regional Handbook in the Content Evaluation of Supplementary Materials, IMCS (2008)

Dick, W., Carey, L., \& Carey, J. O. (2001). The systematic design of instruction (5th ed.). Allyn \& Bacon. 
Flagg, B. N. (1990). Formative evaluation of educational technologies. Hillsdale, NJ: Erlbaum.

Garcia, C. M. (2001). Effects of modular instruction on the performance of college students in pane trigonometry. Bulacan State University, Maolos City. Unpublished Thesis.

Gravoso, (2005). Design and use of instructional materials for student-centered learning: A case in learning ecological concepts, Vol. 7, No. 1, Visayas State University: Asia Pacific Education Researcher

Gutierrez, A. (2014). Development and effectiveness of an educational card game as supplementary material in understanding selected topics in biology. Retrieved from http://www.lifescied.org/content/13/1/76.full.pdf

Hattie, J., \& Timperley, H. (2007). The power of feedback. Retrieved from http://rer.sagepub.com/content/77.full

Hamona, L. A. (2002). Development of prototype pedagogical materials for teacher trainees of basic education. Philippine Normal University.

Jamwal, G. (2012). Effective use of interactive learning modules in classroom study for computer science education. All Graduate Plan B and other Reports. Retrieved from digitalcommons.usu.edu

$\mathrm{K}$ to 12 Basic Education Program (BEP) (2012). Presidential communication development and strategic planning office and department of education. Retrieved from http://www.slideshare.net/mojacko69/the-k-to12-basic-education-program

Koul, R., Fraser, B.J., \& Nastiti, H. (2018). Transdisciplinary instruction: Implementing and evaluating a Primary-School STEM teaching model, International Journal of Innovation in Science and Mathematics Education, 26(8), 17-29, 2018

Macarandang, M. (2009). Evaluation of a proposed set of modules in principles and methods of teaching. EInternational Scientific Research Journal, Vol. 1.

Mercado, Jr., R. B. (2007). Effectiveness of modularized instruction in entrepreneurship. Bulacan State University, Malolos City. Unpublished Thesis.

Naval, D. J. (2014). Development and validation of tenth Grade physics modules based on selected least mastered competencies. International Journal of Education and Research, Vol. 2.

Newby, T. J., Stepich, D. A., Lehman, J. D., \& Russell, J. D. (2006). Evaluation of students and materials in educational technology for teaching and learning. Person Merrill Prentice Hall.

Oakes, J., \& Saunders, M. (2002). Access to textbooks, instructional materials, equipment, and technology: inadequacy and inequality in California's public schools. Retrieved from http://www.ucla-idea.org

Olurinola, O. (2015). Colour in learning: Its effect on the retention rate of graduate students. Retrieved from http://files.eric.ed.gov/fulltext/EJ1080132.pdf

Patton, M. Q. (2011). Developmental evaluation applying complexity concepts to enhance innovation and use. Retrieved from http://www.guilford.com/books/Developmental-Evaluation/Michael-QuinnPatton/9781606238721

Pawson, R. (2013). The science of evaluation: A realist manifesto. Retrieved from https://evaluationcanada.ca/system/files/cjpe-entries/29-2-145.pdf

Peacock, J. (2007). Beyond the fashionable: Strategic planning for critical information literacy education. In S. C. Curzon \& L. D. Lampert (Eds.), Proven strategies for building an information literacy program. (pp. 2954). New York: Neal-Schuman Publishers.

Phillips, J. A. (2013). Module 7: Evaluating the school curriculum from Chapter 8: Curriculum evaluation.

Race, P. (2000). Audit your own teaching. In A. Brown and S. Homes (Ed.). Internal Audit in Higher Education (pp. 163-181). Sterling: Stylus Publishing Inc.

Ranjit, K. (2014). Research methodology: A step-by-step guide for beginners. London: SAGE Publications.

Reardon, S.F., Scott, K., \& Verre, J. (1994). Symposium: equity in educational assessment. Harvard Educational Review, 64 (1), 1-4.

Rodriguez, C. (2015). Status on the use of mother tongue-based and multilingual learning materials in the Division of Calbayog City (Unpublished Doctoral Dissertation). Leyte Normal University, Tacloban City, Philippines.

Ronda, R. A. (2012). Public school teachers welcome passage of kindergarten law.Philstar. Retrieved from http://www.philstar.com/Article.aspx?articleId=778647\&publicationSubCategoryId=63

Rossi, P. H., Freeman, H., \& Lipsey M. W. (2004). Evaluation: A systematic approach. Te, Newburry Park, Ca.

Rouse, M. (2005, September). Definition: Total quality management (TQM). Retrieved from http://searchcio.techtarget.com/definition/Total-Quality-Management.

Salandanan, G.G. (2011). Principles and methods of teaching. Quezon City, Manila: Lorimar Publishung, Inc.

Sañosa, M. (2013). Implementation of K to 12 curriculum program among Grade 7 Science Teachers in Eastern Visayas. Journal of Society and Technology, 3, 37-44

Sarem, S., Hamidi, H. \& Mahmoudie, R. (2013). A critical look at textbook evaluation: A case study of evaluating an ESP course-book: English for international tourism. International Research Journal of Applied and Basic Sciences, 4(2), 372-380. 
Sari, U., Hassan, A., Güven, K. \& Sen, Ö. (2017). Effects of the 5E teaching model using interactive simulation on achievement and attitude in physics education, International Journal of Innovation in Science and Mathematics Education, 25(3),20-35,2017

Scriven, M. (1967). The methodology of evaluation. In R.W. Tyler, R.M. Gagne, \& M. Scriven (Eds.), Perspectives of curriculum evaluation (pp. 39-83). Chicago: Rand McNally.

Sitragool, W. (2003). Project on research study and materials development of a literacy programme for ethnic minority in Omkoi, Chiang Mai (Thailand)", a Paper presented at the Conference on Language Development.

Tomlinson, B. (2011). Introduction: principles and procedures of materials development. In B. Tomlinson (ed.) Materials Development in Language Teaching (second edition) (pp. 1-34). Cambridge: Cambridge University Press

Trends in International Mathematics and Science Studies (TIMSS): Overview (2013). National Center for Education Statistics (NCES), USA. Retrieved from http://nces.ed.gov/timss/index.asp

Villarino, G.N. (2019). Constructivist strategy, microcomputer-based laboratory, and students' alternative conceptions of force and motion. International Journal of Innovation in Science and Mathematics Education, 27(1), 47-60, 2019.

Watson, J., Murin, A., Vashaw, L., Gemin, B., \& Rapp, C. (2013). Keeping pace with K-12 online learning: An annual review of state-level policy and practice. Evergreen, CO: Evergreen Education Group. Retrieved from http://kpk12.com//cms/wp-content/uploads/EEG_KP2013-lr.pdf 